\title{
Worrede $\mathfrak{u}$ witerten Aluflage.
}

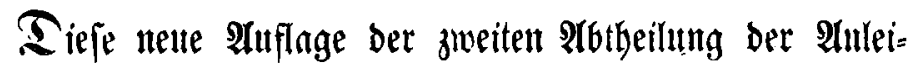
tung zur Bebandlung, Bemtbung uno Sryäbung bet

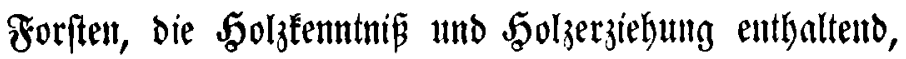

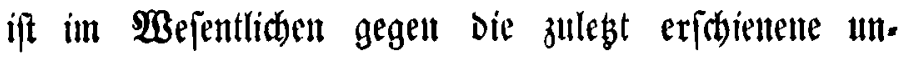
veräubert gebliebert. Doch hat ber $\mathfrak{B e r f a f f e r}$ gefutcht, in iller alle in ber neueften Zeit befannt gewordene, bewäbrte Errfabrungen nadjattragen, fo mie bie volls

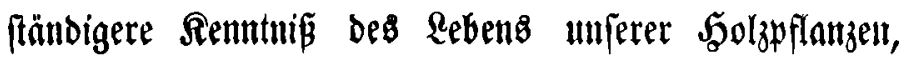

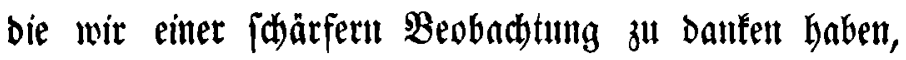
zu bemuken, um ihre (Erziefung und Belyandlung uatur=

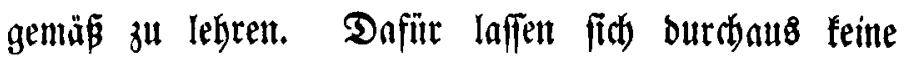

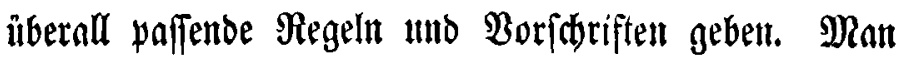

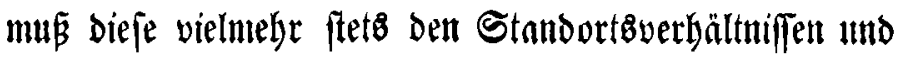

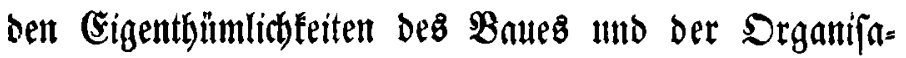
tion jeber bुolzart anpaffen. Danum ift auth bas 
Wisthigfte in biefer Bezielung erwähnt. (Ez foll das outr(b) aber fo menig eine vollfänoige Stnubortålehre

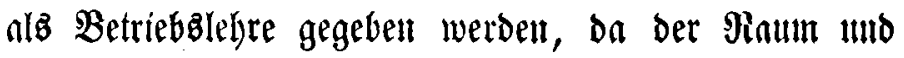

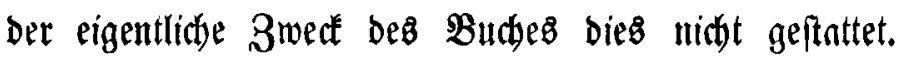
Möge diefe neue Auflage eine fo mad)fidtige uno gïnftige Beltrtbeilung finden, alz bie beiden Yeḩten $\mathscr{A} ı f=$ lagen gefunden baben. - Bemert wird nod), oap



